\title{
COFS syndrome
}

INSERM

\section{Source}

INSERM. (1999). Orphanet: an online rare disease and orphan drug data base. COFS syndrome. ORPHA:1466

Cerebrooculofacioskeletal (COFS) syndrome is a rare genetic disorder, belong ing to a family of diseases of DNA repair, characterized by a severe sensorineural involvement. 